Saudi Journal of Oral and Dental Research

Abbreviated Key Title: Saudi J Oral Dent Res ISSN 2518-1300 (Print) |ISSN 2518-1297 (Online) Scholars Middle East Publishers, Dubai, United Arab Emirates Journal homepage: http://scholarsmepub.com/sjodr/

\title{
Cellular Prosthodontics - A New Revolutionary Era
}

Dr. Beenu $\mathrm{V}^{1}$, Prabu P S ${ }^{2}$, Dr Justin Ninan ${ }^{3}$, Dr. Sanju Thomas ${ }^{3}$, Dr. Neetika Prabu ${ }^{4}$, Dr. Shani J Nair ${ }^{1}$

${ }^{1}$ Post graduate, Malabar Dental College and Research Centre, Edappal, Malappuram, Kerala, India

${ }^{2}$ Professor, Malabar Dental College and Research Centre, Edappal, Malappuram, Kerala, India

${ }^{3}$ Senior Lecturer, Malabar Dental College and Research Centre, Edappal, Malappuram, Kerala, India

${ }^{4}$ R V S Dental College, Kumaran Kottam Campus, Kannampalayam, Coimbatore, Tamil Nadu 641402, India

DOI: $10.36348 /$ sjodr.2019.v04i12.012

| Received: 11.12.2019 | Accepted: 18.12.2019 | Published: 25.12.2019

*Corresponding author: Beenu $\mathrm{V}$

Abstract

Stem cells are biological cells that are undifferentiated and can be differentiate into specialized cells. They are of embryonic or adult stem cell. Another classification is dental pulp and bone marrow- derived. Bone marrow type stem cells are commonly used for regenerative procedures in prosthodontics. They have excellent regenerative ability without neoplasm formation. They help to build the bone structures of the craniofacial region, particularly the maxilla and mandible. Stem cell therapy can revolutionize next era in regenerative prosthodontics.

Keywords: Stem cell, Differentiation, Scaffold, Molecular signalling, Bioengineering, bio-hybrid implant.

Copyright @ 2019: This is an open-access article distributed under the terms of the Creative Commons Attribution license which permits unrestricted use, distribution, and reproduction in any medium for non-commercial use (NonCommercial, or CC-BY-NC) provided the original author and source are credited.

\section{INTRODUCTION}

Ernest A. McCulloch and James E. Till in 1960s at the University of Toronto were the first to venture into the field of stem cells research [1]. The embryonic stem cells aid in the tissue repair mechanism in the body $[2,3]$. The stem cells play an important role in the repair process [4]. When the stem cells interact with each other, they lead to the formation of a new tissue or organ [5]. The differentiated multipotent adult stem cells lie deep within the tissues and aid in repair when needed [6].

\section{TYPES OF STEM CELLS}

Totipotent stem cells are those which produce all types of cells as well as germ cells (ESCs). Pluripotent stem cells produce all types of cells apart from cells of the embryonic membrane. Multipotent stem cells distinguish into more than one adult cell (MSC). Unipotent stem cells produce only one particular cell type [7].

Embryonic Stem Cells are derived from embryos that are 2-11 days old known as blastocysts. Adult Stem Cells are undifferentiated cells that occur in a differentiated tissue. Sources include bone marrow, brain, blood, eye, skeletal muscle, lining of the gastrointestinal tract, pancreas, dental pulp, skin.

\section{TOOTH STEM CELLS}

Based on origin, they are of dental pulp stem cells and teeth derived.

\section{Dental Pulp Stem Cells}

These were discovered by Dr. Songtao Shi, a Pedodontist in 2003. Transplantation of dental pulp stem cells result in the formation of a dentin-like tissue.

\section{Teeth Derived}

Stem cells can be derived from deciduous teeth, wisdom teeth and permanent teeth. Third molars are rich potential sources for stem cells. Premolars extracted for orthodontic treatment are an example of permanent teeth stem cell. Exception for this is endodontically treated or non-vital teeth, teeth with lively infections, teeth with severe periodontal disease, teeth with large restorations and deep caries, and teeth with calcified or sclerosed pulp chambers [8].

\section{STEM CELL THERAPY IN PROSTHODONTICS 1) Tooth Regeneration}

The regeneration of adult teeth will be possible in future with the help of bioengineering. This can be a substitute for dental implants. Research studies have shown that the tooth crown can be regenerated using bio engineering techniques. The procedure is known as inductive morphogenesis. Adult stem cells are harvested and seeded into a scaffold which provides an 
optimal environment. These cells are instructed with molecular signals spatially.

Duailibi et al., in their studies were able to form tooth from suspensions of cultured rat tooth bud cells. Scaffold was PLGA and PGA and bioengineered rat teeth was grown in 12 weeks. Young et al., using porcine tooth bud cells, PLGA and PGA scaffolds produced a crossbreed tooth bone for the cure of tooth loss beside with alveolar bone resorption [9-13].

\section{2) Periodontal Regeneration}

Alveolar bone augmentation is very essential especially for patients with an atrophic alveolar ridge [14]. Conventional bone augmentation techniques include bone grafts. It is typically difficult to maintain the grafted bone height and volume using these techniques. Bone-marrow derived mesenchymal stem cells (BMSCs) have been used to improve bone regeneration [15]. A disadvantage of this is that poor transplant survival due to insufficient vascularization. A possible alternative to this will be a cell mediated bone regeneration technique.

Kawaguchi et al., verified that the transplantation of ex vivo prolonged autologous MSCs can regenerate fresh cementum, periodontal ligament and alveolar bone in dogs. Hasegawa et al., confirmed that periodontal ligament cells cultured in vitro were effectively reimplanted into periodontal defects in order to endorse periodontal regeneration.

\section{3) Craniofacial Regeneration}

Dental derived mesenchymal stem cells were encapsulated in a suitable scaffold like alginate hydrogel. These cells were subjected to molecular signalling [16]. This cell therapy was used in craniofacial tissue augmentation. Clinical and laboratory analyses of treatment sites demonstrated that the cell therapy accelerated the regenerative response [17].

\section{4) Alveolar Bone Regeneration}

In case of serious bone fractures, self-healing repair is not possible. Thus an adequate supply of stem cells (such as bone marrow stem cells) is required for efficient bone regeneration [18]. Oral mesenchymal stem cells are used for bone regeneration. They are able to differentiate into chondroblasts and osteoblasts under inductive conditions in vitro [19].

The aim of prosthodontic treatment should be to regenerate the missing teeth together with the periodontal structures. A bio-hybrid implant using dental follicles induced vertical bone regeneration in a murine three-wall bone defect model was developed (20). Recently, a bioengineered tooth unit was successfully integrated via recipient bone remodelling after transplantation into an extensive bone defect model [21].

\section{CONCLUSION}

Current regenerative prosthodontic treatments which include bone grafts are associated with difficulty in maintaining the grafted bone height and volume. A possible solution to this difficulty includes the application of a dense cellular layer of BMSCs to achieve vertical alveolar bone augmentation without postoperative bone resorption. A bioengineered bone was developed. Bio-hybrid implants and bioengineered teeth are also expected to be provide alternatives to current osseointegrated implants. Purified BMSCs and iPSCs (induced pluripotent stem cells) are expected to be promising cell sources that help to explore, integrate and evolve next-generation regenerative prosthodontics.

\section{REFERENCES}

1. Stem cell - Wikipedia, the free encyclopedia. en.wikipedia. org/wiki/ Stem_cell.

2. Doetschman, T. C., Eistetter, H., Katz, M., Schmidt, W., \& Kemler, R. (1985). The in vitro development of blastocyst-derived embryonic stem cell lines: formation of visceral yolk sac, blood islands and myocardium. Development, 87(1), 2745.

3. Odorico, J. S., Kaufman, D. S., \& Thomson, J. A. (2001). Multilineage differentiation from human embryonic stem cell lines. Stem cells, 19(3), 193204.

4. Behjati, S., Huch, M., van Boxtel, R., Karthaus, W., Wedge, D. C., Tamuri, A. U., ... \& Tarpey, P. S. (2014). Genome sequencing of normal cells reveals developmental lineages and mutational processes. Nature, 513(7518), 422-425.

5. Vainio, S., Karavanova, I., Jowett, A., \& Thesleff, I. (1993). Identification of BMP-4 as a signal mediating secondary induction between epithelial and mesenchymal tissues during early tooth development. Cell, 75(1), 45-58.

6. Körbling, M., \& Estrov, Z. (2003). Adult stem cells for tissue repair - a new therapeutic concept?. New England Journal of Medicine, 349(6), 570-582.

7. Desai, V. D., Varma, B., Maheshwari, S., \& Bumb, D. (2012). Tooth Regeneration by Stem Cells-an Innovative Approach. Asian Journal of Pharmaceutical and Health Sciences, 2(3):433437.

8. Cherian, E., Kurien, J., Kurien, A., \& Jayasekharan, V. P. (2013). Stem Cells In Dental Tissue. Ijoonline, 1(1), 26-32.

9. Mouli, P. C., Kumar, S. M., Senthil, B., Parthiban, S., Priya, R., \& Subha, R. (2012). stem cells in dentistry-A review. Journal of Pharmaceutical Sciences and Research, 4(7), 1872-1876.

10. Nakahara, T., \& Ide, Y. (2007). Tooth regeneration: implications for the use of bioengineered organs in first-wave organ replacement. Human cell, 20(3), 63-70.

11. Duailibi, M. T., Duailibi, S. E., Young, C. S., Bartlett, J. D., Vacanti, J. P., \& Yelick, P. C. 
Beenu V et al; Saudi J Oral Dent Res, Dec 2019; 4(12): 844-846

(2004). Bioengineered teeth from cultured rat tooth bud cells. Journal of dental research, 83(7), 523528.

12. Honda, M. J., Sumita, Y., Kagami, H., \& Ueda, M. (2005). Histological and immunohistochemical studies of tissue engineered odontogenesis. Archives of histology and cytology, 68(2), 89-101.

13. Young, C. S., Abukawa, H., Asrican, R., Ravens, M., Troulis, M. J., Kaban, L. B., ... \& Yelick, P. C. (2005). Tissue-engineered hybrid tooth and bone. Tissue engineering, 11(9-10), 1599-1610.

14. Egusa, H., Sonoyama, W., Nishimura, M., Atsuta, I., \& Akiyama, K. (2012). Stem cells in dentistrypart I: stem cell sources. Journal of prosthodontic research, 56(3), 151-165.

15. Egusa, H., Sonoyama, W., Nishimura, M., Atsuta, I., \& Akiyama, K. (2012). Stem cells in dentistryPart II: Clinical applications. Journal of prosthodontic research, 56(4), 229-248.

16. Langer, R., \& Vacanti, J. P. (1993). Tissue engineering. Science. 260(5110):920-926.

17. Pelegrine, A. A., Da Costa, C. E. S., Correa, M. E. P., \& Marques Jr, J. F. C. (2010). Clinical and histomorphometric evaluation of extraction sockets treated with an autologous bone marrow graft. Clinical Oral Implants Research, 21(5), 535542.

18. Dimitriou, R., Jones, E., McGonagle, D., \& Giannoudis, P. V. (2011). Bone regeneration: current concepts and future directions. $B M C$ medicine, 9(1), 66.

19. Yamada, Y., Ito, K., Nakamura, S., Ueda, M., \& Nagasaka, T. (2011). Promising cell-based therapy for bone regeneration using stem cells from deciduous teeth, dental pulp, and bone marrow. Cell transplantation, 20(7), 1003-1013.

20. Oshima, M., Inoue, K., Nakajima, K., Tachikawa, T., Yamazaki, H., Isobe, T., ... \& Kasugai, S. (2014). Functional tooth restoration by nextgeneration bio-hybrid implant as a bio-hybrid artificial organ replacement therapy. Scientific reports, 4, 6044.

21. Oshima, M., Mizuno, M., Imamura, A., Ogawa, M., Yasukawa, M., Yamazaki, H., ... \& Kasugai, S. (2011). Functional tooth regeneration using a bioengineered tooth unit as a mature organ replacement regenerative therapy. PloS one, 6(7), e21531. 